American Journal of Applied Sciences 7 (4): 518-526, 2010

ISSN 1546-9239

(C) 2010Science Publications

\title{
The Relationship between Credit Market Development and Economic Growth
}

\author{
Antonios Adamopoulos \\ Department of Applied Informatics, University of Macedonia, \\ 34 Solonos Street, 546 44, Thessaloniki, Greece
}

\begin{abstract}
Problem statement: This study investigated the relationship between credit market development and economic growth for Spain for the period 1976-2007 using a Vector Error Correction Model (VECM). Questions were raised whether economic growth spurs credit market development taking into account the negative effect of inflation rate and investments on credit market development. This study aimed to investigate the short-run and the long-run relationship between bank lending, gross domestic product and inflation rate applying the Johansen cointegration analysis. Approach: To achieve this objective classical and panel unit root tests were carried out for all time series data in their levels and their first differences. Johansen cointegration analysis was applied to examine whether the variables are cointegrated of the same order taking into account the maximum eigenvalues and trace statistics tests. Finally, a vector error correction model was selected to investigate the long-run relationship between economic growth and credit market development. Results: A short-run increase of economic growth per $1 \%$ induces an increase of bank lending $0.08 \%$, while an increase of inflation rate per $1 \%$ induces a relative decrease of bank lending per $0.56 \%$ and also an increase of investments rate per $1 \%$ induces an increase of bank credits per $0.18 \%$ in Spain. The estimated coefficient of error correction term is statistically significant and has a negative sign, which confirms that there is not any a problem in the long-run equilibrium between the examined variables. Conclusion: The empirical results indicated that economic growth and investment have a positive effect on credit market development, while inflation rate has a negative effect. Bank development is determined by the size of bank lending directed to private sector at times of low inflation rates leading to higher economic growth rates.
\end{abstract}

Key words: Credit market, economic growth, panel unit roots, vector error correction model

\section{INTRODUCTION}

The relationship between economic growth and credit market development has been an extensive subject of empirical research. The main objective of this study was to investigate the relationship between economic growth and credit market development taking into account the effect of inflation rate on credit market development. Economic growth favors credit market development at times of low inflation rates. This study tries to confirm this hypothesis examining a model of banking system in which bank lending is dependent on gross domestic product and consumer price index.

The literature on financial liberalization encourages free competition among banks as the way forward to achieve economic growth. However, it has largely overlooked the possibility that endogenous constraints in the credit market, such as imperfect information, could be a significant obstacle to efficient credit allocation even when assuming that banks are free from interest rate ceilings.

According to Keynes (1936) study in a minimally developed financial system, credit creation causes economic growth. Credit creation, however, is supposed to be unconstrained by the supply of deposits because of the existence of idle balances in the banking system and because of the possibility of borrowing from the money market or the central bank. Therefore, the availability of money in the financial sector translates into credit creation to finance the economic activity and consequently, results in higher growth.

Financial systems improve economic performance by assessing investment opportunities and exerting corporate control, easing risk management and lowering the costs of resource mobilization (Levine, 1997). As financial systems develop, they become more efficient in providing these services, which enhance economic growth.

Other economists, however, announced skepticism about the capacity of financial systems to affect economic growth (Lucas, 1988). The bank-based theory emphasizes the positive role of banks in development and growth and, also, stresses the shortcomings of market-based financial systems. It is argued that banks can finance development more effectively than markets in developing economies and, in the case of state- 
owned banks, market failures can be overcome and allocation of savings can be undertaken strategically (Gerschenkron, 1962). Those banks that are unhampered by regulatory restrictions, can exploit economies of scale and scope in information gathering and processing (Levine, 2002).

The bank-based view also stresses the shortcomings of market-based systems. The latter reveal information publicly, thereby reducing incentives for investors to seek and acquire information. Information asymmetries are thus accentuated, more so in market-based rather than in bank-based financial systems (Boyd and Prescott, 1986).

Banks can ease distortions emanating from asymmetric information through forming long-run relationships with firms and, through monitoring, contain moral hazard. As a result, bank based arrangements can produce better improvement in resource allocation and corporate governance than market-based institutions (Bhide, 1993).

Ball and Mankiw (1995) indicate that higher inflation necessarily raises inflation uncertainty. Higher inflation uncertainty increases the riskiness of all credits and therefore even previously 'high quality borrowers' get treated as the risky ones. To assure that credits are paid back banks may resort to more severe credit rationing. Arestis et al. (2001) show that while both banks and stock markets play an important role in the growth process, the banking sector development effect on economic growth in the long run is much higher than the stock market development one.

Levine (2002) emphasizes the critical importance of the banking system in economic growth and highlight circumstances when banks can actively spur innovation and future growth by identifying and funding productive investments.

The model hypothesis predicts that economic growth facilitates credit market development taking into account the negative effect of inflation rate on credit market development and economic growth.

This study has two objectives:

- To examine the stationarity tests of the examined variables estimating classical and panel unit roots tests

- To examine the long run relationship among economic growth, interest rate and financial market development using Johansen co-integration analysis taking into account classical and panel unit root tests

The remainder of the study proceeds as follows: Initially the data and the specification of the multivariate VAR model are described. For this purpose stationarity test and Johansen co-integration analysis are examined taking into account the estimation of vector error correction model.

Finally, the empirical results are presented analytically and some discussion issues resulted from this empirical study are developed shortly, while the final conclusions are summarized relatively.

\section{MATERIALS AND METHODS}

Data and specification model: In this study the method of Vector Autoregressive Model (VAR) is applied to estimate the effects of economic growth, domestic investments and inflation rate on credit market development. The use of this methodology predicts the cumulative effects taking into account the dynamic response among credit market development and the other examined variables (Shan, 2005).

In order to test the long-run relationships, the following multivariate model is to be estimated:

$\mathrm{BC}=\mathrm{f}(\mathrm{CPI}, \mathrm{GDP}, \mathrm{INV})$

Where:

$\mathrm{BC}=$ The domestic bank credits to private sector

CPI $=$ The consumer price index

GDP $=$ The gross domestic product

INV $=$ The domestic investments

Following the empirical studies of Vazakidis (2006) and Vazakidis and Adamopoulos (2009c), the variable of economic growth (GDP) is measured by the rate of change of real GDP, while the credit market development is expressed by the domestic bank credits to private sector (BC) as a percentage of GDP.

This measure has a basic advantage from any other monetary aggregate as a proxy for credit market development. Although it excludes bank credits to the public sector, it represents more accurately the role of financial intermediaries in channeling funds to private market participants (Vazakidis and Adamopoulos, 2009a; 2009b).

The data that are used in this analysis are annual covering the period 1976-2007 for Spain, regarding 2000 as a base year and are obtained from international financial statistics yearbook International Monetary Fund (2007). All time series data are expressed in their levels and Eviews econometric computer software is used for the estimation of the model.

Unit root tests: For univariate time series analysis involving stochastic trends, Phillips-Perron (PP) unit 
root test is calculated for individual series to provide evidence as to whether the variables are integrated. This is followed by a multivariate co-integration analysis.

Phillips-Perron (PP) (1988) test is an extension of the Dickey-Fuller (DF) test (1979), which makes the semi-parametric correction for autocorrelation and is more robust in the case of weakly autocorrelation and heteroskedastic regression residuals. According to Choi (1992), the Phillips-Perron test appears to be more powerful than the ADF test for the aggregate data.

Although the Phillips-Perron (PP) test gives different lag profiles for the examined variables (time series) and sometimes in lower levels of significance, the main conclusion is qualitatively the same as reported by the Dickey-Fuller (DF) test. Since the null hypothesis in the Augmented Dickey-Fuller test is that a time series contains a unit root, this hypothesis is accepted unless there is strong evidence against it. However, this approach may have low power against stationary near unit root processes.

The Phillips-Perron unit root test (as cited in Laopodis and Sawhney, 2007) which is very general and can be used in the presence of heteroscedastic and autocorrelated innovations is specified as follows:

$$
\ln (1+\mathrm{r})=\alpha+\beta\left(\frac{\mathrm{t}-\mathrm{T}}{2}\right)+\delta \ln \left(1+\mathrm{r}_{\mathrm{t}-1}\right)+\zeta_{\mathrm{t}}
$$

For $\mathrm{t}=1,2, \ldots \ldots, \mathrm{T}$ where $\mathrm{r}_{\mathrm{t}}$ denotes interest rate at time $t,(t-T / 2)$ is a time trend and $\mathrm{T}$ is the sample size.

Equation 2 tests three hypotheses: The first hypothesis is that the series contains a unit root with a drift with a drift and a time trend: $\mathrm{H}_{0}^{1}: \delta=1$. The second hypothesis is that the series contains a unit root but without a time trend: $\mathrm{H}_{0}^{2}: \beta=0, \delta=1$. The third hypothesis is that the series contains a unit root but without a drift or a time trend: $\mathrm{H}_{0}^{3}: \mathrm{a}=0, \beta=0, \delta=1$. The statistics that are used to test each hypothesis are $\mathrm{Z}$ $\left(\mathrm{t}_{\delta}\right), \mathrm{Z}\left(\Phi_{2}\right), \mathrm{Z}\left(\Phi_{3}\right)$, respectively and their corresponding equations are as follows:

$$
\begin{aligned}
\mathrm{Z}\left(\mathrm{t}_{\delta}\right)= & \left(\frac{\sigma_{0}}{\sigma_{\mathrm{T} 1}}\right) \mathrm{t}_{\sigma}-\left(\frac{\mathrm{T}^{3}}{3^{1 / 2} 4 \mathrm{D}_{\mathrm{xx} \sigma \mathrm{T} 1}^{1 / 2}}\right)\left(\sigma_{\mathrm{Tl}}^{2}-\sigma_{0}^{2}\right) \\
\mathrm{Z}\left(\Phi_{3}\right) & =\left(\frac{\sigma_{0}^{2}}{\sigma_{\mathrm{Tl}}^{2}}\right) \Phi_{3}-\left(\frac{1}{2 \sigma_{\mathrm{Tl}}^{2}}\right)\left(\sigma_{\mathrm{Tl}}^{2}-\sigma_{0}^{2}\right) \\
& \mathrm{x}\left[\mathrm{T}(\delta-1)-\left(\frac{\mathrm{T}^{6}}{48 \mathrm{D}_{\mathrm{xx}}}\right)\left(\sigma_{\mathrm{Tl}}^{2}-\sigma_{0}^{2}\right)\right]
\end{aligned}
$$

$$
\begin{aligned}
& \mathrm{Z}\left(\Phi_{2}\right)=\left(\frac{\sigma_{0}^{2}}{\sigma_{\mathrm{Tl}}^{2}}\right) \Phi_{2}-\left(\frac{1}{3 \sigma_{\mathrm{Tl}}^{2}}\right) \\
&\left(\sigma_{\mathrm{T} 1}^{2}-\sigma_{0}^{2}\right) \times\left[\begin{array}{l}
\mathrm{T}(\delta-1)- \\
\left(\frac{\mathrm{T}^{6}}{48 \mathrm{D}_{\mathrm{xx}}}\right)\left(\sigma_{\mathrm{Tl}}^{2}-\sigma_{0}^{2}\right)
\end{array}\right]
\end{aligned}
$$

where:

$$
\begin{aligned}
& \Phi_{3}=\frac{\mathrm{T}\left(\sigma_{0}^{2}-\left(\overline{\mathrm{r}}-\overline{\mathrm{r}}_{\mathrm{t}-1}\right)^{2}-\sigma^{2}\right)}{2 \sigma^{2}} \\
& \Phi_{2}=\frac{\mathrm{T}\left(\sigma_{0}^{2}-\sigma^{2}\right)}{3 \sigma^{2}}
\end{aligned}
$$

And $\sigma^{2}$ is the OLS residual variance, $\sigma_{0}^{2}$ is the variance under the particular hypothesis for the standard t-test for $\delta=1 . \mathrm{D}_{\mathrm{xx}}$ is the determinant of the $\left(\mathrm{X}^{\prime} \mathrm{X}\right)$, where $\mathrm{X}$ is the $\mathrm{T}_{3}$ matrix of explanatory variables in Eq. 2 .

Finally, $\sigma_{\mathrm{Tl}}$ is a consistent estimator of the variance of $\zeta$ and is computed as follows:

$$
\sigma_{\mathrm{T} 1}^{2}=\sum_{\mathrm{t}=1}^{\mathrm{T}} \frac{\zeta_{\mathrm{t}}^{2}}{\mathrm{~T}}+\frac{\left(2 \sum_{\mathrm{t}=1}^{1} \sum_{\mathrm{t}=\mathrm{s}=1}^{\mathrm{T}}(1-\mathrm{s} /(1+1)) \zeta_{\mathrm{t}} \zeta_{\mathrm{t}-\mathrm{s}}\right)}{\mathrm{T}}
$$

where $\mathrm{s}$ and 1 are the lag truncation numbers and $\mathrm{s}<1$. The estimator $\sigma_{\mathrm{Tl}}$ is consistent under general conditions because it allows for effects of serially correlated and heterogeneously distributed innovations. The three statistics are evaluated under various lags $(1=0$ to 12$)$.

Since the null hypothesis in the Augmented Dickey-Fuller test is that a time series contains a unit root, this hypothesis is accepted unless there is strong evidence against it. However, this approach may have low power against stationary near unit root processes. Kwiatkowski et al. (1992) present a test where the null hypothesis states that the series is stationary.

The KPSS test complements the Augmented Dickey-Fuller test in that concerns regarding the power of either test can be addressed by comparing the significance of statistics from both tests. A stationary series has significant Augmented Dickey-Fuller statistics and insignificant KPSS.

Following the study of Chang (2002), according to Kwiatkowski et al. (1992) the test of KPSS assumes that a time series can be composed into three components, a deterministic time trend, a random walk and a stationary error: 
$y_{t}=\delta t+r_{t}+\varepsilon_{t}$

where, $\mathrm{rt}$ is a random walk $\mathrm{r}_{\mathrm{t}}=\mathrm{r}_{\mathrm{t}-1}+\mathrm{u}_{\mathrm{t}}$. The $\mathrm{u}_{\mathrm{t}}$ is iid $(0$, $\left.\sigma_{\mathrm{u}}^{2}\right)$. The stationarity hypothesis implies that $\sigma_{\mathrm{u}}^{2}=0$.

Under the null, $\mathrm{y}_{\mathrm{t}}$, is stationary around a constant $(\delta=0)$ or trend-stationary $(\delta \neq 0)$. In practice, one simply runs a regression of $y_{t}$ over a constant (in the case of level-stationarity) ore a constant plus a time trend (in the case of trend-stationary). Using the residuals, $e_{i}$, from this regression, one computes the LM statistic:

$\mathrm{LM}=\mathrm{T}^{-2} \sum_{\mathrm{t}=1}^{\mathrm{T}} \mathrm{S}_{\mathrm{t}}^{2} / \mathrm{S}_{\mathrm{\varepsilon t}}^{2}$

where $S_{\varepsilon t}^{2}$ is the estimate of variance of $\varepsilon_{\mathrm{t}}$ :

$\mathrm{S}_{\mathrm{t}}=\sum_{\mathrm{i}=1}^{\mathrm{t}} \mathrm{e}_{\mathrm{i}}, \mathrm{t}=1,2, \ldots \ldots \mathrm{T}$

The distribution of LM is non-standard: The test is an upper tail test and limiting values are provided by Kwiatkowski et al. (1992) via Monte Carlo simulation. To allow weaker assumptions about the behavior of $\varepsilon_{t}$, one can rely, following Phillips (1987) on the Newey and West (1987) estimate of the long-run variance of $\varepsilon_{t}$ which is defined as:

$\mathrm{S}^{2}(\mathrm{l})=\mathrm{T}^{-1} \sum_{\mathrm{t}=1}^{\mathrm{T}} \mathrm{e}_{\mathrm{i}}^{2}+2 \mathrm{~T}^{-1} \sum_{\mathrm{s}=1}^{\mathrm{l}} \mathrm{w}(\mathrm{s}, 1) \sum_{\mathrm{t}=\mathrm{s}+1}^{\mathrm{T}} \mathrm{e}_{\mathrm{i}} \mathrm{e}_{\mathrm{i}-\mathrm{k}}$

where, $\mathrm{w}(\mathrm{s}, 1)=1-\mathrm{s} /(1+1)$. In this case the test becomes:

$v=\mathrm{T}^{-2} \sum_{\mathrm{t}=1}^{\mathrm{T}} \mathrm{S}_{\mathrm{t}}^{2} / \mathrm{S}^{2}(1)$

which is the one considered here. Obviously the value of the test will depend upon the choice of the 'lag truncation parameter', 1. Here we use the sample autocorrelation function of $\Delta \mathrm{e}_{\mathrm{t}}$ to determine the maximum value of the lag length 1) statistics.

The KPSS statistic tests for a relative lagtruncation parameter (1), in accordance with the default Bartlett kernel estimation method (since it is unknown how many lagged residuals should be used to construct a consistent estimator of the residual variance), rejects the null hypothesis in the levels of the examined variables for the relative lag-truncation parameter (1).

Besides classical unit roots in this study the methodology of panel units roots tests is examined.

Following the study of Christopoulos and Tsionas (2004), Levin et al. (2002) denoted as LLC panel unit root tests respectively resulted to the same conclusion. They consider the following basic ADF specification:

$$
\Delta y_{i t}=\alpha y_{i t-1}+\sum_{j=1}^{p_{i}} \beta_{i j} \Delta y_{i t-j}+X_{i t}^{\prime} \delta+\varepsilon_{i t}
$$

where we assume a common $\alpha=\rho-1$ but allow the lag order for the difference terms, $p_{i}$ to vary across cross-sections. The null and alternative hypotheses for the tests may be written as: $\mathrm{H}_{0}$ : $\mathrm{a}=0$ but $\mathrm{H}_{1}$ : $\mathrm{a}<0$. In LLC panel unit root test, the null hypothesis is the existence of a unit root, while under the alternative, there is no unit root.

Levin et al. (2002) consider the model:

$$
y_{i t}=\rho_{i} y_{i, t-1}+z_{i t}^{\prime} \gamma+u_{i t}
$$

where, $Z_{i t}$ are deterministic variables, $U_{i t}$ is $\operatorname{iid}\left(0, \sigma^{2}\right.$ and $\rho_{i}=\rho$. They assume that there is a common unit root process so that $\rho_{1}$ is identical across cross-sections.

The LLC test statistic is a t-statistic on $\rho$ given by:

$$
\mathrm{t}_{\rho}=\frac{(\hat{\rho}-1) \sqrt{\sum_{\mathrm{i}=1}^{N} \sum_{\mathrm{t}=1}^{\mathrm{T}} \tilde{y}_{\mathrm{i}, \mathrm{t}-1}^{2}}}{\mathrm{~s}_{\mathrm{e}}}
$$

Where:

$$
\begin{aligned}
& \tilde{y}_{i t} \quad=y_{i t}-\sum_{s=1}^{T} h(t, s) y_{i s} \\
& \tilde{u}_{i t} \quad=u_{i t}-\sum_{s=1}^{T} h(t, s) u_{i s} \\
& h(t, s)=z_{t}^{\prime}\left(\sum_{t=1}^{T} z_{t} z_{t}^{\prime}\right) z_{s} \\
& s_{e}^{2} \quad=(N T)^{-1} \sum_{i=1}^{N} \sum_{t=1}^{T} \tilde{u}_{i t}^{2} \\
& \hat{\rho} \quad=\text { The OLS estimate of } \rho
\end{aligned}
$$

It can be shown that if there are only fixed effects in the model, then:

$$
\sqrt{\mathrm{N}} \mathrm{T}(\hat{\rho}-1)+3 \sqrt{\mathrm{N}} \rightarrow \mathrm{N}\left(0, \frac{51}{5}\right)
$$

and if there are fixed effects and a time trend:

$$
\sqrt{\mathrm{N}}(\mathrm{T}(\hat{\rho}-1)+7.5) \rightarrow \mathrm{N}\left(0, \frac{2895}{112}\right)
$$

Im et al. (2003) denoted as IPS panel unit root tests respectively resulted to the same conclusion. In IPS 
panel unit root test, the null hypothesis is the existence of a unit root. The IPS statistic is based on averaging individual Dickey-Fuller unit root test $\left(\mathrm{t}_{\mathrm{i}}\right)$ according to:

$\mathrm{t}_{\mathrm{IPS}}=\frac{\sqrt{\mathrm{N}}\left(\overline{\mathrm{t}}-\mathrm{E}\left[\mathrm{t}_{\mathrm{i}} \mid \rho_{\mathrm{i}}=0\right]\right)}{\sqrt{\operatorname{var}\left[\mathrm{t}_{\mathrm{i}} \mid \rho_{\mathrm{i}}=0\right]}} \rightarrow \mathrm{N}(0,1)$

where, $\overline{\mathrm{t}}=\mathrm{N}^{-1} \sum_{\mathrm{i}=1}^{\mathrm{N}} \mathrm{t}_{\mathrm{i}}$. The moments of $\mathrm{E}\left[\mathrm{t}_{\mathrm{i}} \mid \rho_{\mathrm{i}}=0\right]$ and $\operatorname{var}\left[\mathrm{t}_{\mathrm{i}} \mid \rho_{\mathrm{i}}=0\right]$ are obtained by Monte Carlo simulation and are tabulated in IPS (Christopoulos and Tsionas, 2004).

The econometric software Eviews which is used to conduct the PP and KPSS tests, reports the simulated critical values based on response surfaces. The results of the Phillips-Perron (1988) unit root test and of Levin et al. (2002) and Im et al. (2003) panel unit roots tests for each variable appear in Table 1. If the time series (variables) are non-stationary in their levels, they can be integrated with integration of order 1 , when their first differences are stationary.

Johansen co-integration analysis: Since it has been determined that the variables under examination are integrated of order 1 , then the co-integrated test is performed. The testing hypothesis is the null of non-cointegration against the alternative that is the existence of co-integration using the Johansen maximum likelihood procedure (Johansen, 1988).

Once a unit root has been confirmed for a data series, the question is whether there exists a long-run equilibrium relationship among variables. According to Granger (1986), a set of variables, $Y_{t}$ is said to be cointegrated of order $(d, b)$-denoted $C I(d, b)$-if $Y_{t}$ is integrated of order $d$ and there exists a vector, $\beta$, such that $\beta^{\prime} Y_{t}$ is integrated of order (d-b).

Co-integration tests in this study are conducted using the method developed by Johansen and Juselius (1990). The multivariate co-integration techniques developed by Johansen and Juselius (1990; 1992) using a maximum likelihood estimation procedure allows researchers to estimate simultaneously models involving two or more variables to circumvent the problems associated with the traditional regression methods used in previous studies on this issue. Therefore, the Johansen method applies the maximum likelihood procedure to determine the presence of cointegrated vectors in non-stationary time series.

Following the study of Chang and Caudill (2005), Johansen (1988) and Osterwald-Lenum (1992) propose two test statistics for testing the number of co-integrated vectors (or the rank of $\Pi$ ): The trace $\left(\lambda_{\text {trace }}\right)$ and the maximum eigenvalue $\left(\lambda_{\max }\right)$ statistics.

The Likelihood Ratio statistic (LR) for the trace test $\left(\lambda_{\text {trace }}\right)$ as suggested by Johansen (1988) is:

$\lambda_{\text {trace }}(\mathrm{r})=-\mathrm{T} \sum_{\mathrm{i}=\mathrm{r}+1}^{\mathrm{p}} \ln \left(1-\bar{\lambda}_{\mathrm{i}}\right)$

Where:

$\hat{\lambda}_{i}=$ The largest estimated value of ith characteristic root (eigenvalue) obtained from the estimated $\Pi$ matrix

$\mathrm{r}=0,1,2, \ldots \mathrm{p}-1$

$\mathrm{T}=$ The number of usable observations

The $\lambda_{\text {trace }}$ statistic tests the null hypothesis that the number of distinct characteristic roots is less than or equal to $r$, (where $r$ is 0,1 , or 2 ) against the general alternative. In this statistic $\lambda_{\text {trace }}$ will be small when the values of the characteristic roots are closer to zero (and its value will be large in relation to the values of the characteristic roots which are further from zero).

Alternatively, the maximum eigenvalue $\left(\lambda_{\max }\right)$ statistic as suggested by Johansen is:

$\lambda_{\max }(\mathrm{r}, \mathrm{r}+1)=-\mathrm{T} \ln \left(1-\hat{\lambda}_{\mathrm{r}+1}\right)$

The $\lambda_{\max }$ statistic tests the null hypothesis that the number of $\mathrm{r}$ co-integrated vectors is $\mathrm{r}$ against the alternative of $(\mathrm{r}+1)$ co-integrated vectors. Thus, the null hypothesis $r=0$ is tested against the alternative that $r=1, r=1$ against the alternative $r=2, r=2$ against the alternative $r=3$ and so forth. If the estimated value of the characteristic root is close to zero, then the $\lambda_{\max }$ will be small.

It is well known that Johansen's co-integration tests are very sensitive to the choice of lag length. Firstly, a VAR model is fitted to the time series data in order to find an appropriate lag structure. The Schwarz Criterion (SC) (1978) is used to select the number of lags required in the co-integration test.

The Schwarz Criterion (SC) suggested that the value $p=2$ is the appropriate specification for the order of VAR model for Spain. Table 2 shows the results from the Johansen co-integration test.

Vector error correction model: Following the studies of Chang (2002), Chang and Caudill (2005), since the variables included in the VAR model are co-integrated, the next step is to specify and estimate a Vector Error Correction Model (VECM) including the error correction term to investigate dynamic behavior of the model. 
Am. J. Applied Sci., 7 (4): 518-526, 2010

Table 1: PP, KPSS unit root tests

\begin{tabular}{|c|c|c|c|c|c|}
\hline \multirow[b]{2}{*}{ Variables } & \multicolumn{3}{|l|}{ PP_test stat } & \multicolumn{2}{|c|}{ KPSS test stat } \\
\hline & $\mathrm{Z}\left(\Phi_{3}\right)$ & $\mathrm{Z}\left(\Phi_{2}\right)$ & $\mathrm{Z}\left(\mathrm{t}_{\delta}\right)$ & $\mathrm{h}_{\mathrm{c}}$ & $\mathrm{h}_{\mathrm{t}}$ \\
\hline \multicolumn{6}{|l|}{ In levels } \\
\hline CPI & $-2.57(8) * *, *$ & $-1.43(\mathrm{k}=2)$ & $-1.23(\mathrm{k}=2)$ & $0.75(1=4)$ & $0.70(1=0)$ \\
\hline $\mathrm{BC}$ & $3.39(\mathrm{k}=0)$ & $8.10(\mathrm{k}=0)$ & $5.16(\mathrm{k}=0)$ & $1.66(1=0)$ & $0.49(1=0)$ \\
\hline GDP & $-1.11(\mathrm{k}=0)$ & $4.59(\mathrm{k}=0)$ & $1.14(\mathrm{k}=0)$ & $2.98(1=0)$ & $0.53(1=0)$ \\
\hline INV & $-0.56(\mathrm{k}=4)$ & $4.68(\mathrm{k}=1)$ & $1.48(\mathrm{k}=1)$ & $2.70(1=0)$ & $0.56(1=0)$ \\
\hline \multicolumn{6}{|c|}{ In 2nd differences } \\
\hline$\Delta \mathrm{CPI}$ & $-5.01(\mathrm{k}=0)$ & $-4.91(\mathrm{k}=0)$ & $-4.81(\mathrm{k}=0)$ & $0.05(1=0)$ & $0.04(1=0)$ \\
\hline$\Delta \mathrm{BC}$ & $-6.67(\mathrm{k}=0)$ & $-6.96(\mathrm{k}=0)$ & $-7.18(\mathrm{k}=0)$ & $0.18(1=0)$ & $0.06(1=0)$ \\
\hline$\Delta \mathrm{GDP}$ & $-5.95(\mathrm{k}=0)$ & $-5.92(\mathrm{k}=0)$ & $-5.83(\mathrm{k}=0)$ & $0.04(1=0)$ & $0.03(1=0)$ \\
\hline$\Delta \mathrm{INV}$ & $-4.29(\mathrm{k}=0)$ & $-431(\mathrm{k}=0)$ & $-4.26(\mathrm{k}=0) *$ & $0.09(1=0)$ & $0.04(1=0)$ \\
\hline
\end{tabular}

$\mathrm{Z}\left(\Phi_{3}\right), \mathrm{Z}\left(\Phi_{2}\right), \mathrm{Z}\left(\mathrm{t}_{\mathrm{\delta}}\right)$, are the PP statistics, $\mathrm{h}_{\mathrm{c}}$ and $\mathrm{h}_{\mathrm{t}}$ are the KPSS statistics. $\mathrm{k}, \mathrm{l}=$ bandwidth lengths: Newey-West using Bartlett kernel. The critical values at 1,5 and $10 \%$ are $-2.62,-1.94,-1.61$, for $Z\left(\Phi_{3}\right),-3.60,-2.93,-2.60$ for $Z\left(\Phi_{2}\right)$, and for $-4.19,-3.52,-3.19$ for $Z\left(t_{\delta}\right)$, respectively. The critical values at 1,5 and $10 \%$ are $0.73,0.46$ and 0.34 for $\mathrm{h}_{\mathrm{c}}$ and $0.21,0.14$ and 0.11 for $_{\mathrm{t}}$ respectively (Kwiatkowski et al., 1992, Table 1). *,**, ***: Indicate that those values are not consistent with relative hypotheses at the $1 \%, 5 \%$ and $10 \%$ levels of significance relatively

Table 2: IPS, LLC panel unit root tests

\begin{tabular}{lcccc}
\hline & \multicolumn{2}{c}{ LLC test stat } & \multicolumn{2}{l}{ IPS test stat } \\
Variables & LLC $_{\mathrm{C}}$ & LLC $_{\mathrm{T}}$ & IPS $_{\mathrm{C}}$ & IPS $_{\mathrm{T}}$ \\
\hline In levels & & & & \\
CPI & -0.004 & -0.09 & -1.93 & -0.93 \\
BC & 0.330 & 0.31 & 8.10 & 5.16 \\
GDP & 0.030 & -0.02 & 4.59 & 1.14 \\
INV & 0.050 & 0.04 & 6.11 & 2.31 \\
In 2nd differences & & & \\
$\Delta$ CPI & -0.960 & -0.96 & -4.91 & -4.81 \\
$\Delta$ BC & -1.350 & -1.38 & -6.96 & -7.18 \\
$\Delta$ GDP & -1.130 & -1.14 & -5.92 & -5.83 \\
$\Delta$ INV & -1.110 & -1.15 & -4.31 & -4.26 \\
\hline
\end{tabular}

Notes: LLC is the Levin, Lin, and Chu t-test and IPS is the Im, Pesaran and Shin t-test test for unit root test in the model. The critical values for $L_{L C}$ test are 0.72 and -9.65 including only constant in levels and second differences respectively. The critical values for $\mathrm{LLC}_{\mathrm{T}}$ test are 4.90 and -7.30 including constant and trend in levels and second differences respectively. The critical values for IPS $_{\mathrm{c}}$ test are 12.95 and -8.99 including only constant in levels and second differences respectively. The critical values for $\mathrm{IPS}_{\mathrm{T}}$ test are 9.89 and -8.04 including only constant and trend in levels and second differences respectively

Once the equilibrium conditions are imposed, the VEC model describes how the examined model is adjusting in each time period towards its long-run equilibrium state.

Since the variables are co-integrated, then in the short run, deviations from this long-run equilibrium will feed back on the changes in the dependent variables in order to force their movements towards the long-run equilibrium state. Hence, the co-integrated vectors from which the error correction terms are derived are each indicating an independent direction where a stable meaningful long-run equilibrium state exists.

The VEC specification forces the long-run behavior of the endogenous variables to converge to their co-integrated relationships, while accommodates short-run dynamics. The dynamic specification of the model allows the deletion of the insignificant variables, while the error correction term is retained. The size of the error correction term indicates the speed of adjustment of any disequilibrium towards a long-run equilibrium state (Engle and Granger, 1987). The error-correction model with the computed $\mathrm{t}$-values of the regression coefficients in parentheses is reported in Table 3.

The final form of the Error-Correction Model (ECM) was selected according to the approach suggested by Hendry (Maddala, 1992). The general form of the Vector Error Correction Model (VECM) is the following one:

$$
\begin{aligned}
\Delta \mathrm{Y}_{\mathrm{t}} & =\beta_{1} \sum_{\mathrm{i}}^{\mathrm{n}} \Delta \mathrm{Y}_{\mathrm{t}-\mathrm{i}}+\beta_{2} \sum_{\mathrm{i}}^{\mathrm{n}} \Delta \mathrm{X}_{\mathrm{t}-\mathrm{i}} \\
& +\beta_{3} \sum_{\mathrm{i}}^{\mathrm{n}} \Delta \mathrm{Z}_{\mathrm{t}-\mathrm{i}}+\lambda \mathrm{EC}_{\mathrm{t}-\mathrm{i}}+\varepsilon_{\mathrm{t}}
\end{aligned}
$$

Where:

$\Delta \quad=$ The first difference operator

$\mathrm{EC}_{\mathrm{t}-1}=$ The error correction term lagged one period

$\lambda=$ The short-run coefficient of the error correction term $(-1<\lambda<0)$

$\varepsilon_{\mathrm{t}} \quad=$ The white noise term

\section{RESULTS}

The observed t-statistics fail to reject the null hypothesis of the presence of a unit root for all variables in their levels confirming that they are nonstationary at 1, 5 and $10 \%$ levels of significance (Table 1). However, the results of the PP, KPSS, LLC and IPS tests show that all variables are stationary of the same order when they are transformed into their second differences (Table 2). 
Am. J. Applied Sci., 7 (4): 518-526, 2010

Table 3: Johansen Co-integration tests (BC, GDP, CPI, INV)

\begin{tabular}{lcccc}
\hline Johansen test statistics \\
- \\
Testing & Critical value & & \\
Hypothesis & $\lambda_{\text {trace }}$ & $5 \%$ & $\lambda_{\max }$ & $5 \%$ \\
\hline None* & 51.9200 & 39.81 & 37.9300 & 23.92 \\
At most 1 & 13.9800 & 24.05 & 11.5800 & 17.68 \\
At most 2 & 2.4000 & 12.36 & 2.4000 & 11.03 \\
At most 3 & 0.0004 & 4.16 & 0.0004 & 4.16 \\
\hline Trace test and maximum eigenvalue tests indicate 1 co-integrating \\
eqn(s) at the 0.05 level. *: Denotes rejection of he hypothesis at the \\
0.05 level. **: MacKinnon-Haug-Michelis (1999) p-values
\end{tabular}

Therefore, all series that are used for the estimation are non-stationary in their levels, but stationary and integrated of order two I(2), in their second differences. These variables can be cointegrated as well, if there are one or more linear combinations among the variables that are stationary.

The co-integration vector of the model of Spain has rank $r<p(r=1)$. The process of estimating the rank $r$ is related with the assessment of eigenvalues, which are the following for Spain: $\bar{\lambda}_{1}=0.72$, $\hat{\lambda}_{2}=0.32, \hat{\lambda}_{3}=0.07, \hat{\lambda}_{4}=0.0001$, (Table 3).

For Spain, critical values for the trace statistic defined by Eq. 5 are 39.81 for none co-integrating vectors and 24.05 for at most one vector, 12.36 for at most two vectors, 4.36 for at most three vectors at the 0.05 level of significance as reported by MacKinnon et al. (1999), while critical values for the maximum eigenvalue test statistic defined by Eq. 6 are 23.92 for none co-integrating vectors, 17.68 for at most one vector and 11.03 for at most two vectors and 4.16 for at most three vectors respectively (Table 3 ).

Then the error-correction model with the computed t-values of the regression coefficients in parentheses is estimated. The dynamic specification of the model allows the deletion of the insignificant variables, while the error correction term is retained by the estimation of the co-intergrated vector.

A short-run increase of economic growth per $1 \%$ induces an increase of bank credits per $0.08 \%$, while an increase of consumer price index per $1 \%$ induces a decrease of bank credits per $0.56 \%$ and also an increase of investments rate per $1 \%$ induces an increase of bank credits per $0.18 \%$ for Spain (Table 4 ).

The estimated coefficient of $\mathrm{EC}_{\mathrm{t}-1}$ is statistically significant and has a negative sign, which confirms that there is not any problem in the long-run equilibrium relation between the independent and dependent variables in 5\% level of significance, but its relatively value $(-0.10)$ for Spain shows a satisfactory rate of convergence to the equilibrium state per period (Table 4).

\section{DISCUSSION}

The model of banking system is mainly characterized by the effect of interest rates, investments and the circulation of money. However, bank development is determined by the size of bank lending directed to private sector at times of low inflation rates leading to higher economic growth rates. Businesses make new investments to innovative products through bank lending in more developed countries.

Interest rate is not included in the estimated model of banking system due to the insignificance of estimation results. The significance of the empirical results is dependent on the variables under estimation.

Less empirical studies have concentrated on examining the relationship between economic growth and credit market development taking into account the effect of inflation rate and investments rate. Most empirical studies examine the relationship between economic growth and stock market development.

The results of this study are agreed with the studies of Khan et al. (2006) and Levine et al. (2000). However, more interest should be focused on the comparative analysis of empirical results for the rest of European Union members-states in future research.

\section{CONCLUSION}

This study employs with the relationship between credit market development and economic growth for Spain, using annually data for the period 1976-2007. For univariate time series analysis involving stochastic trends, Phillips-Perron (1988) and Kwiatkowski et al. (1992) classical unit roots tests and Levin et al. (2002) and Im et al. (2003) panel unit roots tests are calculated for individual series to provide evidence as to whether the variables are stationary and integrated of the same order.

The empirical analysis suggested that the variables that determine financial market development present a unit root. Therefore, all series are stationary and integrated of order two I (2), in their second differences. Since it has been determined that the variables under examination are stationary and integrated of order 2, then the Johansen co-integration analysis is performed taking into account the maximum likelihood procedure. 
Am. J. Applied Sci., 7 (4): 518-526, 2010

Table 4: Vector error correction model

\begin{tabular}{llllll}
\hline Dependent variable constant & $\Delta^{2} \mathrm{BC}_{\mathrm{t}-\mathrm{i}}$ & $\Delta^{2} \mathrm{GDP}_{\mathrm{t}-\mathrm{i}}$ & $\Delta^{2} \mathrm{CPI}_{\mathrm{t}-\mathrm{i}}$ & ect $_{\mathrm{t}-1}$ \\
\hline$\Delta^{2} \mathrm{BC}_{\mathrm{t}}$ & -0.0003 & 0.08 & 0.18 & -0.56 & -0.10 \\
& {$[-0.03]$} & {$[0.16]$} & {$[0.41]$} & {$[-0.36]$} & {$[-1.90]$} \\
F-stat $=1.92$ & $\mathrm{DW}=2.50$ & $\mathrm{AIC}=-3.28$ & $\mathrm{SC}=-3.04$ & & \\
\hline
\end{tabular}

Notes: [ ]: I denote the t-statistic values; $\Delta^{2}$ : Denotes the second differences of the variables; DW: Durbin-Watson statistic; AIC=Akaike criterion; SC: Schwarz Criterion

The short run dynamics of the model is studied by analyzing how each variable in a co-integrated system responds or corrects itself to the residual or error from the co-integrating vector. This justifies the use of the term error correction mechanism.

The Error Correction (EC) term, picks up the speed of adjustment of each variable in response to a deviation from the steady state equilibrium. The dynamic specification of the model suggests deletion of the insignificant variables while the error correction term is retained. The VEC specification forces the longrun behavior of the endogenous variables to converge to their co-integrating relationships, while accommodates the short-run dynamics.

A short-run increase of economic growth per $1 \%$ leaded to an increase of bank credits per $0.08 \%$, while an increase of consumer price index per $1 \%$ leaded to a decrease of bank credits per $0.56 \%$ and also an increase of investments rate per $1 \%$ leaded to an increase of bank credits per $0.18 \%$ in Spain.

Therefore, it can be inferred that economic growth and investments have a positive effect on credit market development taking into account the negative effect of inflation rate on credit market development and economic growth.

\section{REFERENCES}

Arestis, P., P. Demetriades and K. Luintel, 2001. Financial development and economic growth: The role of stock markets. J. Mon. Credit Bank., 33: 16-41. http://ideas.repec.org/p/kee/keeldp/97-05.html

Ball, L. and G. Mankiw, 1995. Relative-price changes as aggregate supply shocks. Q. J. Econ., 110: 161-93. http://ideas.repec.org/a/tpr/qjecon/v110y1995i1p16 1-93.html

Bhide, A., 1993. The hidden costs of stock market liquidity. J. Fin. Econ., 34: 1-51. http://ideas.repec.org/a/eee/jfinec/v34y1993i1p3151.html

Boyd, J. and E., Prescott, 1986. Financial intermediarycoalitions. J. Econ. Theory, 38: 211-232. http://ideas.repec.org/p/fip/fedmsr/87.html

Chang, T., (2002) An econometric test of Wagner's law for six countries based on cointegration and errorcorrection modelling techniques, Applied
Economics, $\quad$ 34(9), $\quad$ 1157-1169 http://ideas.repec.org/a/taf/applec/v34y2002i9p115 7-69.html

Chang, T., and Caudill, S., (2005) Financial development and economic growth: the case of Taiwan, Ap. Econ., 37: 1329-1335 DOI: 10.1080/0003684042000338702.

Choi, I., 1992. Effects of data aggregation on the power of the tests for a unit root. Econ. Lett., 40: $\quad 397-401$. http://ideas.repec.org/a/eee/ecolet/v40y1992i4p397 $-401 . h t m l$

Christopoulos, D. and E. Tsionas, 2004. Financial development and economic growth: Evidence from panel unit root and cointegration tests. J. Dev. Econ., 73: 5-74. http://web.ku.edu/ intecon/ourses/Econ915/papers/financegrowth_jde04.pdf

Dickey, D. and W. Fuller, 1979. Distributions of the estimators for autoregressive time series with a unit root. J. Am. Stat. Assoc., 74: 427-431. http://www.jstor.org/pss/2286348

Engle, R. and C. Granger, 1987. Co-integrated and error correction: Representation, estimation and testing. Econometrica, 55: 251-276. http://www.stat.purdue.edu/ ntuzov/Niks\%20files/ Research/papers/stat_arb/EG\%201987.pdf

Gerschenkron, A., 1962. Economic Backwardness in Historical Perspective-A Book of Essays. $1^{\text {st }}$ edition, Harvard University Press, Cambridge, ISBN: 10: 0-674-22600-3, p. 468.

Granger, C. 1986. Developments in the study of cointegrated economic variables. Oxford Bull. Econ. Stat., $\quad 48:$ 213-228. http://econpapers.repec.org/article/blaobuest/v_3a4 83ay_3a1986_3ai_3a3_3ap_3a213-28.htm

Im, S., H. Peasaran and Y. Shin, 2003. Testing for units roots in heterogeneous panels, J. Econometrics 115:

53-74. http://ideas.repec.org/a/eee/econom/v115y2003i1p 53-74.html

International Monetary Fund, 2007. International Financial Statistics Yearbook Country notes, 2007 English ed., International Monetary Fund Publisher, ISBN: 1589066503, p. 867.

Johansen, S. and K. Juselious, 1990. Maximum likelihood estimation and inference on cointegrated with applications to the demand for the 
Am. J. Applied Sci., 7 (4): 518-526, 2010

money. Oxford Bull. Econ. Stat., 52: $\quad$ 169-210. http://time.dufe.edu.cn/wencong/jjwx/mleic.pdf

Johansen, S. and K. Juselius, 1992. Testing structural hypotheses in a multivariate co-integrated analysis at the purchasing power parity and the uncovered interest parity for the UK. J. Econ., 53: 211-244. http://ideas.repec.org/p/kud/kuiedp/9005.html

Johansen, S., 1988. Statistical analysis of co-integrated vectors. J. Econ. Dyn. Control, 12: 231-254. htmlhttp://ideas.repec.org/a/eee/dyncon/v12y1988i 23p231-254. html

Keynes, J., 1936. The General Theory of Employment Interest and Money. Macmillan, London, ISBN: 10: 1573921394, pp: 403.

Khan, M. A. Senhadji and B. Smith, 2006. Inflation and financial depth. Macr. Dynamics, 2:165182,http://ideas.repec.org/a/cup/macdyn/v10y2006i 02p165-182_05.html

Kwiatkowski, D., P. Phillips, P. Schmidt and Y. Shin, 1992. Testing the null hypothesis of stationarity against the alternative of a unit root. J. of Econometr., $\quad 54$ : 159-178. http://ideas.repec.org/p/cwl/cwldpp/979.html

Laopodis, N.T. and B.L. Sawhney, 2007. Dynamic interactions between investment and the stock market evidence from cointegration and error correction models. Applied Financ. Econ., 17: 257269. DOI: $10.1080 / 09603100600694327$

Levin, A., F. Lin and C. Chu, 2002. Unit Root Tests in Panel Data: Asymptotic and Finite-Sample Properties. J. Econometr., 108, pp.1-24. http://www.cenet.org.cn/userfiles/201013/2010010 3182407954.pdf

Levine, R., 1997. Financial development and economic growth: Views and agenda, J. Econ. Lit., 35: 688726.http://ideas.repec.org/a/aea/jeclit/v35y1997i2p 688-726.html

Levine, R., 2002. Bank based or market-based financial systems: Which is better? J. Fin. Intermediat., 11: 398-428.

http://ideas.repec.org/a/eee/jfinin/v11y2002i4p398428.html

Levine, R., N. Loyaza and T. Beck, 2000. Financial intermediation and growth: Causality and causes. J. Monetary Econ., 46: 31-77. http://ideas.repec.org/a/eee/moneco/v46y2000i1p3 1-77.html

Lucas, R. 1988. On the mechanics of economic development. J. Mon. Econ., 22: 3-42. http://ideas.repec.org/a/eee/moneco/v22y1988i1p342.html
MacKinnon, J., A. Haug and L. Michelis, 1999. Numerical distribution functions of likelihood ratio tests for cointegration. J. Applied Econ., 14: 563-577. http://www3.interscience.wiley.com/cgibin/fulltext /66001312/PDFSTART

Maddala, G., 1992. Introduction to Econometrics. 2nd Edn., Macmillan, New York, USA., ISBN: 0023745452 , pp: 663.

Newey, W. and K. West, 1987. A simple, positive semi-definite, heteroskedasticity and autocorrelation consistent covariance matrix. Econometrica, 55: 703-708. http://ideas.repec.org/a/ecm/emetrp/v55y1987i3p7 03-08.html

Osterwald-Lenum, M., 1992. A Note with quantiles of the asymptotic distribution of the maximum likelihood cointegration rank test statistics, Oxford Bul. Econ. Stat., 54: 461-472.

Phillips, P. and P. Perron, 1988. Testing for a unit root in time series regression. Biometrika, 75: 335-346. http://ideas.repec.org/p/cwl/cwldpp/795r.html

Phillips, P., 1987. Time Series Regression with Unit Roots. Econometrica, 2: 277-301. http://ideas.repec.org/p/cwl/cwldpp/740r.html

Schwarz, R., 1978. Estimating the dimension of a model. Ann. Stat., 6: 461-464. http://projecteuclid.org/DPubS? service=UI\&versio $\mathrm{n}=1.0 \&$ verb=Display\&handle=euclid.aos $/ 1176344$ 136

Shan, J., 2005. Does financial development lead economic growth? A vector autoregression appraisal. Applied Econ., 37: 1353-1367. http://ideas.repec.org/a/taf/applec/v37y2005i12p13 53-1367.html

Vazakidis, A. and A. Adamopoulos, 2009a. Credit market development and economic growth. Am. J. Econ. Bus. Admin., 1: 34-40. http://www.scipub.org/fulltext/ajeba/ajeba113440.pdf

Vazakidis, A. and A. Adamopoulos, 2009b. Financial development and economic growth: An empirical analysis for Greece. Am. J. Applied Sci., 6: 1408-1415. http://www.scipub.org/fulltext/ajas/ajas6714101417.pdf

Vazakidis, A. and A. Adamopoulos, 2009c. Stock market development and economic growth. Am. J. Applied Sci., 6: 1933-1941. http://www.scipub.org/fulltext/ajas/ajas61119331941.pdf

Vazakidis, A., 2006. Testing simple versus Dimson market models: The case of Athens Stock Exchange. Int. Res. J. Finance Econ., 2: 26-34. http://www.eurojournals.com/IRJFE\%202\%203\%2 0Vazakidis.pdf 